\title{
The first record of Cryptops bortensis (Donovan, 1810) (Chilopoda: Scolopendromorpha: Cryptopidae) in Belarus
}

\author{
Первая находка Cryptops bortensis (Donovan, 1810) \\ (Chilopoda: Scolopendromorpha: Cryptopidae) в Беларуси
}

\begin{abstract}
A.M. Ostrovsky
A.M. Островский

Gomel State Medical University, Lange str. 5, Gomel 246000 Republic of Belarus. E-mail: Arti301989@mail.ru Гомельский государственный медицинский университет, ул. Ланге 5, Гомель 246000 Республика Беларусь.

KEY WORDS: Cryptops hortensis, faunistics, synathropy, Belarus.

КЛЮЧЕВЫЕ СЛОВА: Cryptops hortensis, фаунистика, синантропия, Беларусь.
\end{abstract}

ABSTRACT. The centipede Cryptops hortensis (Donovan, 1810) from the family Cryptopidae, found in the city of Gomel in autumn 2016, is new to the fauna of Belarus. The record is clearly synathropic. Data on the global distribution of the species are presented.

How to cite this article: Ostrovsky A.M. 2018. The first record of Cryptops hortensis (Donovan, 1810) (Chilopoda: Scolopendromorpha: Cryptopidae) in Belarus // Arthropoda Selecta. Vol.27. No.1. P.31-32. doi: 10.15298/arthsel. 27.1.03

PЕЗЮМЕ. Многоножка Cryptops hortensis (Donovan, 1810) из семейства Cryptopidae, найденная в городе Гомель осенью 2016 г., новый для фауны Беларуси. Находка явно синантропная. Обобщены данные по мировому распространению вида.

\section{Introduction}

The order Scolopendromorpha is distributed almost worldwide, with the maximum species richness in tropical and subtropical regions, and it encompasses about 700 species [Edgecombe, Bonato, 2011]. The synanthropic centipede fauna of Belarus still remains very poorly studied, the latest records concerning Scutigera coleoptrata (Linnaeus, 1758) [Ostrovsky, 2016a, b]. Continuing our research, Cryptops hortensis (Donovan, 1810) has been found introduced into Belarus. Both the genus Cryptops Leach, 1815 and the family Cryptopidae to which it belongs are almost ubiquitous with the exception of Antarctica, mainly occurring both in temperate and tropical regions [Bonato, Zapparoli, 2011].

Results

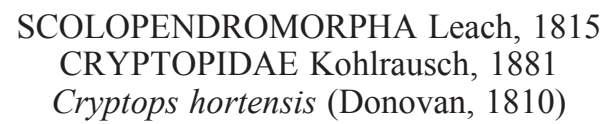

MATERIAL EXAMINED. 5 ad., Republic of Belarus, Gomel Area, Gomel, the A.V. Lunacharsky Central Park, Sozh River bank, among household waste, 24.09.2016, all leg. et det. A.M. Ostrovsky.

Four of the above samples have been deposited in the author's collection, but one specimen has been donated to the collection of the Zoological Museum of the Moscow State University.

DISTRIBUTION. Being Central Asian-European in origin, the cryptopid scolopendromorph $C$. hortensis is widespread across most of Europe, currently known from Albania, Austria, Belgium, Bosnia and Hercegovina, Bulgaria, Croatia, Czech Republic, Denmark, mainland and insular Greece including Crete and the Dodecanese islands, Great Britain including the Channel Islands and Northern Ireland, Finland, mainland France including Corsica, Germany, Hungary, Ireland, mainland Italy as well as Sicily and Sardinia, Macedonia, Monaco, Montenegro, the Netherlands, Norway, Poland, mainland Portugal as well as the Azores and Madeira, Romania, the European part of Russia (south of the Moscow Area, the Caucasus, the Krasnodar Province, the Stavropol Province), the Asian part of Russia (the city of Tomsk, Tomsk Area, the city of Barnaul, Altai Province), San Marino, Slovakia, Slovenia, mainland Spain and the Canary Islands, Sweden, Switzerland and Ukraine; also distributed in Western and Central Asia, inhabiting Armenia, Azerbaijan, Georgia, Tajikistan, Turkey, Turkmenistan and Uzbekistan, as well as Morocco. The species is also introduced to the United States including the Hawaiian Islands, Canada, St. Helena Island, Australia including Tasmania and Christmas Island [Zalesskaja, Schileyko, 1991, 1992; Lewis, 2011; Minelli, Foddai, 2013; Zuev, 2016; Bonato et al., 2016; Korobushkin et al., 2016; Nefediev et al., 2016].

The family Cryptopidae, the genus Cryptops Leach, 1815, as well as the widespread, often introduced $C$. hortensis, are all formally new to the centipede fauna of Belarus, reported from an anthropogenic habitat alone.

\section{Conclusion}

The family, genus and species are formally new to Belorussia's list: Cryptopidae, Cryptops Leach, 1815, and Cryptops hortensis (Donovan, 1810). The sole record is strictly confined to a synanthropic habitat. 

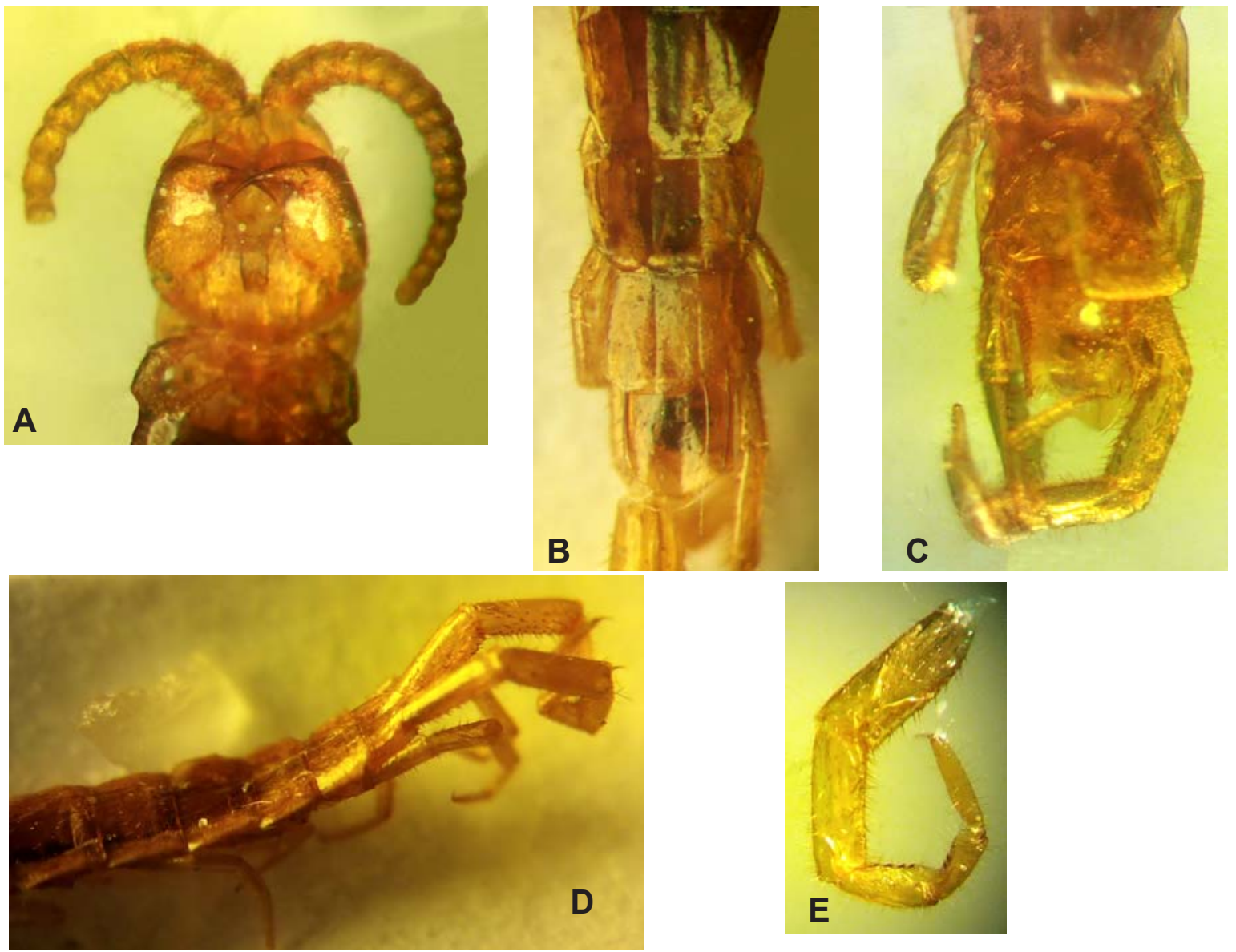

Fig. 1. Structural details of Cryptops hortensis (Donovan, 1810) from the city of Gomel: A - anterior part of body, ventral view; B rear tergites; C - posterior part of body, ventral view; D - posterior part of body, lateral view; E — prefemur, femur, tibia and tarsus of leg 21.

Рис. 1. Детали строения Cryptops hortensis (Donovan, 1810) из города Гомеля: А - передний конец тела, вид снизу; В задние тергиты; C - задний конец тела, вид снизу; D — задний конец тела, вид сбоку; Е — предбедро, бедро, голень и лапка ноги 21-й пары.

\section{References}

Bonato L., Chagas Junior A., Edgecombe G.D., Lewis J.G.E., Minelli A., Pereira L.A., Shelley R.M., Stoev P., Zapparoli M. 2016. ChiloBase 2.0 - A World Catalogue of Centipedes (Chilopoda). Available at http://chilobase.biologia.unipd.it (accessed 19 November 2017)

Bonato L., Zapparoli M. 2011. Chilopoda - Geographical distribution // Minelli A. (ed.). Treatise on Zoology - Anatomy, Taxonomy, Biology. The Myriapoda. Vol.1. Leiden-Boston: Brill. P.327-337.

Edgecombe G.D., Bonato L. 2011. Chilopoda - Taxonomic review. Order Scolopendromorpha // Minelli A. (ed.). Treatise on Zoology - Anatomy, Taxonomy, Biology. The Myriapoda. Vol.1. Leiden-Boston: Brill. P.392-407.

Korobushkin D.I., Semenyuk I.I., Tuf I.H. 2016. An annotated checklist of the Chilopoda and Diplopoda (Myriapoda) of the Abrau Peninsula, northwestern Caucasus, Russia // Biodiversity Data Journal. Vol.4: e7308. P.1-33. DOI: 10.3897/BDJ.4.e7308.

Lewis J.G.E. 2011. A review of the species in the genus Cryptops Leach, 1815 from the Old World related to Cryptops (Cryptops) hortensis (Donovan, 1810) (Chilopoda, Scolopendromorpha) // International Journal of Myriapodology. Vol.4. P.1150. DOI: $10.3897 / \mathrm{ijm} .4 .1116$.

Minelli A., Foddai D. 2013. Fauna Europaea: Cryptopidae // Fauna Europaea, version 2.6. Available at http://www.fauna-eu.org (accessed 19 November 2017).
Nefediev P.S., Tuf I.H., Dyachkov Yu.V. 2016. First record of Cryptops (Cryptops) hortensis (Donovan, 1810) in southwestern Siberia, Russia (Chilopoda: Scolopendromorpha: Cryptopidae) // Biological Bulletin of Bogdan Chmelnitskiy Melitopol State Pedagogical University. Vol.6. No.2. P.107-109. DOI: $10.15421 / 201642$.

Ostrovsky A.M. 2016a. The first records of Scutigera coleoptrata (Linnaeus, 1758) (Chilopoda: Scutigeromorpha: Scutigeridae) from Belarus // Arthropoda Selecta. Vol.25. No.4. P.355-356.

Ostrovsky A.M. 2016b. [Distribution and biology of the house centipede, Scutigera coleoptrata (Linnaeus, 1758), in the territory of Belarus] // Biospeleologicheskie issledovaniya v Rossii i sopredel'nykh gosudarstvakh. Materialy II Vserossiyskoy molodezhnoy konferentsii. Yaroslavl: Filigran Publ. P.81-86 [in Russian].

Zalesskaja N.T., Schileyko A.A. 1991. [The scolopendromorph centipedes (Chilopoda, Scolopendromorpha)]. Moscow: Nauka Publ. 103 p. [in Russian]

Zalesskaja N.T., Schileyko A.A. 1992. The distribution of Scolopendromorpha in the USSR (Chilopoda) // Berichte des naturwissenschaftlich-medizinischen Vereins in Innsbruck. Vol.10. P.367-372.

Zuev R.V. 2016. Centipedes (Chilopoda) from the Stavropol Territory, northern Caucasus, Russia // Arthropoda Selecta. Vol.25. No.1. P.23-38.

Responsible editor S.I. Golovatch 